\title{
BIOGRAFI PAYUNG BANGUN: PENDIDIK DAN PENGAJAR YANG KONSISTEN BERKARYA
}

Risa Christina ${ }^{1}$

Yushar Tanjung ${ }^{2}$

SMPN 8 Tanjungpinang ${ }^{1}$ Fakultas Ilmu Sosial Universitas Negeri Medan ${ }^{2}$

risasimatupang05@gmail.com

\begin{abstract}
ABSTRAK
Tulisan ini bertujuan untuk mengetahui aktivitas intelektual seorang guru besar Antropologi Sosial,kontribusinya berupa karya-karya di bidang pendidikan, kebudayaan dan sejarah tokoh. Kajian ini menggunakan metode deksriftif kualitatif melalui penelitian lapangan dan kepustakaan.Kajian lapangan dilaksanakan dengan melakukan wawancara terhadap keluarga dan kerabat sedangkan penelitian kepustakan dilakukan dengan cara mengumpulkan karyakarya tertulisBeliau yang dapat mendukung kajian guna dianalisis kemudian disajikan dalam pembahasan. Hasil kajian diperoleh bahwa aktivitas intelektual Payung Bangun sangat dipengaruhi pemikiran beliau ketika sebagai mahasiswa dan menjadi asisten Prof.M. Yamin dalam membantu mata kuliah Sejarah Indonesia dan sejarah Asia Tenggara. Ini membawa Payung Bangun terus berdedikasi di dunia pendidikan,dan pengajaran sebagai Dosen dan membimbing mahasiswa hingga menyelesaikan perkuliahan. Karya-karya tertulis yang disumbangkan untuk pengembangan akademik khususnya Sejarah adalah buku Kolonel Maludin Simbolon,Pendidik dan Pejuang Melanchton Siregar, Dari Medan Area ke Sipirok Area,Terang itu Sudah Menyinari,Pelapisan Sosial di Kabanjahe.Dari tulisannya dapat disimpulkan bahwa konsistensi beliau dalam pendidikan dan pengajaran tertuang dalam tulisan beliau di buku-buku dan artikel yang dibuatnya bahwa Pendidikan Pengajaran Sejarah dalam menumbuhkan dan mengembangkan Nasionalisme.
\end{abstract}

Kata Kunci: Pendidik, pengajar konsisten, Payung Bangun 


\section{PENDAHULUAN}

Sebagai Sub Sistem dalam Sistem Budaya,Pendidikan tidak dapat lepas dari kehidupan manusia secara nyata maupun abstrak.Dengan sifatnya yang mutlak dalam semua aspek kehidupan berbangsa dan bernegara. Perkembangan pendidikan saat ini tidak berdiri sendiri banyak variable yang mempengaruhinya selain system yang berlaku dan para tokoh yang menjadi pencetus gagasangagasan untuk kemudian diaflikasikan para peminat dan pegiat pendidikan. Para pegiat pendidikan adalah mereka yang menyampaikan pesan-pesan pendidikan kepada khalayak pembelajar.Pada momen inilah pegiat pendidik berperan dan dituntut konsistensinya sebagai yang digugu dan bertanggung jawab secara moral membina generasi muda agar teguh dalam mencitai bangsa dan Negara selamanya.

Peran pengajar dalam menumbuhkembangkan pembelajar selain melalui kegiatan tatap muka juga dapat dilakukan melalui karya-karya tulis yang dipublikasikan di media massa atau berupa buku-buku yang terkait dengan dunia akademik. Penyaluran gagasan kependidikan yang tertuang dalam tulisan menunjukkan konsistensi dalam dunia yang ditekuni dan menghasilkan makna yang kuat dalam pembinaan karakter para generasi yang terkait dengan pembelajaran.Peran tokoh dalam kegiatan pembelajaran perlu ditelisik untuk mendapatkan konsistensi watak yang menjadi ujud pembentukan karakter yang aplikatif.Apalagi mereka adalah panutan yang patut digugu terlebih pada era yang sangat cepat berubah ini sebagai konsekwensi perkembangan teknologi komunikasi melalui jaringan yang tanpa batas.Pemikiran-pemikiran para tokoh perlu terus digali dan dikomunikasikan agar dapat di up date untuk menemukan makna yang sejati dari gagasan yang ada.

Sebagai contoh adalah ketokohan Wahidin Soedirohoesodo dalam pendidikan,melalui pemikirannya dibentuklah organisasi sosial,ekonomi dan kebudayaan“Boedi Oetomo"yang bertujuan membantu anak bangsa melanjutkan pendidikan (Ricklefs,2009:354). Pemikiran-pemikiran lainnya yang muncul melalui Soekarno yang melahirkan Pancasila, Moh. Hatta yang melahirkan 
pemikiran mengenai koperasi dan Mohammad Yamin dengan gagasan Nasionalismenya yang kuat dan tertanam dalam sanubari.

Munculnya pemikiran-pemikiran di berbagai bidang yang tidak ada hentinya menunjukkan dinamika kependidikan di tanah air terus meningkat sehingga mampu memberi konstribusi yang jelas dalam pembangunan bangsa seiring berkembangannya ilmu pengetahuan dan teknologi di Indonesia. Selain pemikir yang disebutkan di atas ada lagi akademikus yang telah mencapai tingkat pendidikan yang tinggi dan memegang Ijazah S 3 dengan gelar Doktor bidang AntropologiSosial, sebagai seorang pendidik beliau mencapai jabatan Fungsional Guru Besar Golongan IV/e.Perolehan ini menjadi cemeti bagi beliau untuk terus berkarya dalam dunia akademik karena baginya perkembangan ilmu pengetahuan dan teknologi menantang imanjinasi dan kematangan sikap ilmiah melahirkan buah pikiranya (ide) dalam berbagai bidang. Rasa ingin tahu yang kuat terhadap ilmu pengetahuan yang terpatri dalam pemikiran Payung Bangun merangsang beliau untuk menularkannya kepada generasi muda melalui berbagai tulisan..

Ide dan gagasan Payung Bangun tersemai hidup dalam pikiran bersama masyarakat yang pernah berinteraksi sebagai dosen/guru dengan mahasiswa yang mampu memberi nuansa keilmuan yang bermakna dan berjiwa nasionalis yang kokoh dan dalam.Sebagai seorang pendidikan,Payung Bangun aktif dalam organisasi Perkumpulan Intelektual Kristen Indonesia (PIKI) yang menjadi salah satu indikator ketokohan beliau di dunia intlektual.dan menghantar beliau menjadi salah seorang diantara dua ratus orang pakar Ilmu Pengetahuan dan Tehnologi pada masa Presiden Soeharto Payung Bangun juga aktif dan salah satu tokoh Partai Kristen Indonesia (PARKINDO) yang pusi dengan PDI .Pada Orde Baru pemerintah mengeluarkan peraturan bahwa PNS tidak boleh berpolitik dan hanya menjadi Golkar telah menadikan beliau lepas dari Parkindo Keaktifan Payung Bangun dalam berbagai aspek ini secara otamatis mempengaruhi pemikiran Payung Bangun yang bisa kita lihat dari karya-karyanya di bidang Sejarah, Antropologi dan Pendidikan.

Menulis merupakan kemampuan intlektual dalam menyampaikan gagasan yang telah terinternalisasi dalam pikiran yang dapat dikomunikasian dengan baik 
pada setiap khalayak khususnya para akademikus.Penulisan dapat menjadi puncak segala-galanya yang menunjukan keberadaan dan eksistensi seseorang yang kreatif dan aktifitasnya dalam meneliti dan menuangkan ide pikirannya. Melalui karya yang dihasilkan, masyarakat mempunyai bahan penilaian tentang gagasan dan pikiran yang telah tertuangkan dalam karyanya tersebut. Inilah yang menjadi daya tarik untuk menulis tema ini Hal ini sangat menarik karena Payung Bangun yang merupakan salah satu guru besar telah banyak memberikan buah pikirannya tidak hanya untuk kajian kebudayaan, sejarah juga di bidang pendidikan.Agar lebih terarah kajian ini maka diajukan persoalan apa saja karya tulis beliau yang dapat menunjukkan konsistensi dan aktivitas Payung Bangun dalam bidang eilmuan.Untuk mengelaborasi persoalan ini dipergunakan metode historic heuristic Berdasarkan latar belakang di atas, maka yang menjadi masalah adalah bagaimana aktivitas intelektual Payung Bangun dalam menyalurkan pemikirannya sehingga menampilkan karya-karya tulis yang bernuansa akademik Persoalan ini akan dibahas dengan pendekatan historik melalui penelusuran sumber yang relevan kemudian diverifikasi agar lebih mudah mengklassifikasiskannya dalam penulisannya menjadi bahan telaah.

\section{METODE DAN FOKUS PENELITIAN}

Metode yang digunakan dalam penelitian ini adalah metode penelitian sejarah. Teknik pengumpulan data yang digunakan antara lain: Field Research (penelitian lapangan), selanjutnya mengkaji literatur dan sumber lain guna memperoleh data. Metode Studi Lapangan ini dilakukan dengan mencari dan mengumpulkan data dan juga mengolah data sebanyak-banyaknya dari data yang ada di lapangan. Metode ini dilakukan dengan menggunakan pendekatan deskriptif kualitatif dengan strategi penelitian yang mengungkapkan fakta yang jelas tentang gejala-gejala yang ada pada suatu objek penelitian. Studi pustaka (Library Research) digunakan untuk untuk melengkapi teknik pengumpulan data, maka sebagai pelengkap untuk memperoleh pengetahuan dari berbagai literatur dan arsip-arsip atau dokumen, artikel-artikel yang berkaitan dengan topik penelitian serta literatur lain yang memuat aktifitas tokoh Payung Bangun. 


\section{PEMBAHASAN}

\section{Riwayat Hidup Payung Bangun}

Bukanlah hal aneh dalam menelusuri rekam jejak intlektual seseorang acap dimulai dari riwayat hidupnya sejak dilahirkan sampai mencapai puncak karir. Sebagai pribadi,Payung Bangun di lahir di sebuah desa yang sejuk dan nyaman dengan suasana pegunungan dari Gunng Sinabung,desa tempat beliau dilahirkan adalah Payung pada 23 Februari 1932 yang menjadi tempat tinggal sebelum menlanjutkan kehidupan dengan bersekolah Sekolah Rakyat di Brastagi sampai tahun 1948Payung Bangun menyelesaikan jenjang sekolah dasar pada Sekolah Rakyat di Berastagi pada tahun 1948.Tidak diperoleh rekam jejak beliau yang signifikan sejak lahir sampai menyelesaikan pendidikan dasar di Brastagi. Kehidupan beliau seperti kehidupan anak-anak desa lainnya yang dilingkungi suasana.Pendidikan beliau di lanjutkan ke jenjang SMP yang terdapat di Kaban Jahe, ini artinya beliau berpindah dari Brastagi ke Kaban Jahe dari tahun 1948 sampai menyelesaikan pendidikannya tahun 1951.Gairah beliau dalam dunia pendidikan dapat kita simak secara kronologis tanpa ada selang dan se muanya diikuti jauh dari kampung halamannya pada masa ini dimana transportasi masih belum se modern sekarang. Dalam usia yang sangat muda beliau harus meninggalkan kampong halamannya lebih jauh lagi yakni ke Medan untuk menempuh pendidikan yang lebih tinggi lagipada tahun 1951.Beliau melanjut di SMA Negeri 2 Medan tahun 1951.yang diselesaikan tepat waktu yakni 3 tahun pada tahun 1954.

Payung Bangun tidak pernah puas dengan capaiannya ini dengan mengenyam pendidikanakan sampai jenjang sekolah menengah atas saja. Beliau kemudian melajutkan pendidikannya dengan memilih bidang kajian atau Jurusan Sejarah Budaya di Universitas Padjadjaran di Bandung. Di sinipun beliau menyelesaikan pendidikannya dengan tepat waktu dan meraih gelar kesarjanaan dalam bidang Pendidikan Sejarah 1960 Setelah mendapatkan gelar sarjana pendidikan tahun 1960 bukan berarti perjalan menimba ilmu yang dirintis beliau dari desa kecil di kaki gunung Sinabung Tanah Karo sampai gunung Pangrango di Bandung Jawa Barat telah selesai.Beliau menlanjutkan karir sebagai pendidik 
sesuai dengan gelar kesarjanaan yang diperoleh. Karir petamanya adalah sebagai pengajar Sejarah dan sekaligus sebagai Sekretaris Jurusan Sejarah di Universitas Andalas Padang yang dijabat beliau sampai 1965. Dengan kerja keras dan kemauan yang kuat untuk mengabdi bagi bangsa dan Negara yang sedang menata pembangunan bidang pendidikan telah menghantar beliau untuk kembali ke Sumatera Utara tepatnya di Medan yang menjadi awal perantauan meninggalkan Tanah Karo untuk menempuh SMA.Kali ini beliau ke Medan adalah dalam tugas membina dan mengembangkan Jurusan Pendidikan Sejarah yang di buka pada FKIP USU. Dari sini beliau juga aktif terlibat dalam menumbuhkembangkan lembaga pendidikan keguruan untuk mempersiapkan dan melahirkan pendidik yang kompeten di Sumatera Utara .Penumbuhan IKIP sebagai lembaga tenaga kependidikan memang sangat mendesak agar pelayanan bidang pendidikan tidak hanya mengharap bantuan dari pusat, putra daerah tentu siap mengisi jabatan ini sebagai pengejawantahan pengabdian membangun pendidikan yang baik. Untuk itulah pada tahun 1965 di tubuhkanlah Jurusan Pendidikan Sejarah yang di Ketuai oleh Drs.Payung Bangun sampai tahun 1967 di Fakultas Keguruan Pengetahuan Sosial.Pengabdiannya pada IKIP Medan dilanjutkan dengan jabatan yang diembannya sebagai Dekan FKPS IKIP Medan tahun 1967-1969.

Sarjana Pendidikan yang diperolehnya kemudian dilanjutkan lagi mengikuti Program Master dan memperoleh gelar Master of Art tahun 1970 dari University of California dalam kajian Asian Studies dengan spesialisasi China. Dalam bincang-bincang penulis dengan beliau selagi masih aktif mengajar di Jurusan Pendidikan Sejarah FIS Unimed sekarang dimana penulis adalah Asisten beliau dalam mata pelajaran Sejarah Indonesia zaman HinduBuddha(1995),diungkapkan bahwa ketertarikan beliau mengambil Study China tidak lepas dari semakin memanasnya perang dingin antara Barat dengan Timur.Sebagai kekuatan politik yang berpengaruh kiranya perlu mempelajari China dari dalam,menurut beliau China hendaknya dipandang sebagai kekuatan sosial dan politik yang harus difahami dengan baik agar terjalin hubungan yang simbiosis mutualisma saling menguntungkan dalam derajat setara China adalah 
fenomena yang tidak bisa diabaikan begitu saja dalam hubungan apapun terlebih di saat ini.

Program Doktor diselesaikan di Universitas Indonesia pada tahun 1981 dengan disertasinya Pelapisan Sosial di Kabanjahe. Setahun setelahnya, Payung Bangun diangkat menjadi Guru Besar Antropologi Sosial.Sebagai Dosen di Jurusan Pendidikan Sejarah tentu beliau lebih dikenal sebagai Sejarawan dari pada Antropolog.Kehadiran beliau dalam forum ilmiah acap sebagai seorang Sejarawan.Wawancara dari media massa selalu terkaitb dengan sejarah.....? Hingga tahun 1970-an Payung Bangun dikenal sebagai pakar sejarawan Indonesia terutama melalui tulisan beliau mengenai Kolonel Maludin Simbolon, masyarakat akan menunjuk Payung Bangun bila mencari sebuah nama yang dianggap punya kapasitas dalam hal membicarakan sejarah di Sumatra Utara khususnya Karo. Namun setelah memperoleh gelar doktor (1981), masyarakat lebih mengenal beliau sebagai pakar antorpologi. Selain itu hal itu diperkuat karena beliau lebih sering berbicara mengenai kajian antorpologi bersama Koentjaraningrat.

\section{Karya-Karya Tertulis Payung Bangun}

\section{Pelapisan Sosial di Kabanjahe.}

Merupakan hasil penelitian Payung Bangun untuk menyelesaikan program doktornya $(\mathrm{PhD})$ di Universias Indonesia pada tahun 1981. Hasil penelitian beliau ini mengemukakan struktur pelapisan sosial yang ada di Kabanjahe. Penelitian beliau ini tidak mengungkapkan semua struktur pelapisan sosial yang ada di Kabanjahe. Penelitian ini memusatkan perhatian pada pelapisan sosial yang diwujudkan oleh orang-orang Karo yang merupakan mayoritas dari penduduk yaitu $60 \%$ dari penduduk dari kota ini. Selain orang Karo masih ada orang lain di Kabanjahe seperti orang Toba, Simalungun, Dairi, Minangkabau, Jawa dan Cina. Orang Karo adalah penduduk asli kota tersebut dan daerah yang mengelilinginya, Tanah Karo.

Pelapisan sosial diartikan sebagai lapisan-lapisan kedudukan sosial yang tersusun dalam urutan-urutan yang hirarki. Lapisan-lapisan kedudukan tersebut merupakan perwujudan dari adanya ketidaksamaan tingkat kedudukan yang ada 
dalam masyarakat. Dalam disertasinya ini, Payung Bangun menuliskan beberapa teori yang berusaha menjelaskan gejala ketidaksamaan tingkatan kedudukan sosial. Di antara teori-teori tersebut dituliskan teori Karl Marx yaitu teori pertentangan kelas dan teori Max Weber yang mengadakan perbedaan kelas, kedudukan dan kekuasaan.

Pengkajian tentang pelapisan sosial di Kabanjahe ini melihat ketidaksamaan derajat yang ada dalam masyarakat sebagai perwujudan dari ketidaksamaan tingkat kedudukan yang timbul karena adanya penilaian yang berbeda yang diberikan anggota masyarakat.

Dalam masyarakat Karo terdapat 3 sistem pelapisan sosial, yaitu sistem pelapisan sosial tradisional yang berdasarkan jenis kelamin, senioritas, keturunan dan hubungan kekerabatan; sistem pelapisan sosial agama yang berdasarkan ketaatan dan pengetahuan agama; sistem pelapisan "Indonesia" yang berdasarkan pendidikan, pengalaman, modal dan hubungan-hubungan. Sesuai dengan dasar yang dipakai, maka kedudukan-kedudukan orang Karo ada yang tertutup yaitu berdasarkan kualitas keturunan atau kelahiran dan ada yang terbuka yaitu berdasarkan kualitas bukan keturunan atau perbuatan dan milik seperti kedudukan-kedudukan atau lapisan sosial dalam pelapisan sosial agama dan "Indonesia"

Adanya beberapa sistem pelapisan sosial tidak hanya terdapat dalam masyarakat Kabanjahe. Masyarakat lain yang mempunyai pertumbuhan kebudayaan yang bersamaan dengan Kabanjahe besar kemungkinan akan mempunyai lebih dari satu sistem pelapisan sosial kecuali masyarakat yang terisolasi. Di Indonesia ditemukan masyarakat-masyarakat yang pertumbuhan kebudayaannya mengalami masuknya pengaruh-pengaruh dari luar yaitu pengaruh agama-agama dunia dan pengaruh negeri atau daerah lain yang berarti masyarakat tersebut mempunyai setidaknya tiga jenis pelapisan sosial. 
2. Makalah Aktif “Tuntutan Kehidupan Tahun 2000-an" dalam Seminar Kebudayaan Karo dan Kehidupan Masa Kini.

Makalah aktif yang disampaikan dalam "Seminar Kebudayaan Karo dan Kehidupan Masa Kini” hal yang pertama sekali dibahas oleh Payung Bangun adalah pemikiran beliau mengenai kebudayaan Karo yang melahirkan pertanyaan tentang fungsionalisasi dan meningkatkan fungsi kebudayaan Karo sebagai salah satu modal budaya dalam usaha mewujudkan perikehidupan yang dicita-citakan dan meningkatkan mutu kehidupan yang telah ada. Hal ini ditambahkan beliau karena munurut beliau proses pembangunan bangsa pada saat itu berlatar belakang budaya non Indonesia.

Payung Bangun mengemukakan bahwa kehidupan masa kini penuh dengan tantangan-tantangan khususnya masyarakat Karo. Tantangan-tantangan itu dating langsung dalam kehidupan orang Karo sendiri dari kehidupan sebagai bahagian dari suatu bangsa dan dari pertumbuhan dan kemajuan dunia yang tidak dapat lagi dihindari oleh orang Karo.

Tantangan itu semakin lama semakin besar, diantaranya dalam bentuk persaingan-persaingan yang semakin keras dan semakin meluas, yang pada awalnya hanya persaingan bersifat individual dan keluarga, namun sekarang ditambah lagi dengan persaingan yang bersifat aliran, paham, kepentingan dan sebagainya; mencakup bidang yang luas yang hampir di seluruh segi dan lapangan kehidupan.

Selain itu muncul juga tantangan akan kebutuhan untuk tetap sebagai orang Karo tetapi sekaligus sebagai orang Indonesia, yang mana selain sebagai pendukung dan pelaku tradisi Karo, orang Karo juga harus mempunyai kemampuan ilmu dan teknologi yang maju. Ini berarti orang Karo harus berperan serta dalam kemajuan namun tetap juga menghormati keterikatan-keterikan primordial serta mampu untuk terlibat dalam keterikatan-keterikatan non primordial. 


\section{Terang Itu Sudah Menyinari (Perjumpaan Kekristenan dan Budaya Suku Bangsa di Sumatera Utara)}

Buku ini diterbitkan oleh Lembaga Penerbitan Universitas Kristen Indonesia pada Februari 2003. Buku yang berhalamankan 143 halaman ini memuat lima tulisan yang kemudian dikumpulkan menjadi satu dengan tujuan mencoba mengungkap apa yang telah terjadi dan berlangsung dalam kehidupan orang-orang Batak. Faktor dan ajaran Kekristenan dilihat telah memberikan sumbangan dan pengaruh besar di dalamnya.

Dalam tulisan pertama "Kekristenan dan Habatahon" diuraikan suasana awal dari pertemuan yaitu berkembang dari semacam eksklusivisme Kristiani yang melihat segala sesuatu yang asing baginya sebagai "kafir" yang harus dibuang. Namun pemahaman tentang segala sesuatu yang asing itu berangsurangsur hilang berkat pengkajian yang lebih lanjut dan lebih mendalam tentang makna yang terkandung dalam budaya-budaya pribumi dan apa fungsinya bagi kehidupan masyarakat pendukungnya. Hasilnya adalah akulturasi budaya tanpa harus terjadi sinkretisme agama.

Tulisan yang kedua, "Interaksi Adan dan Injil” memaparkan bagaimana pertemuan dan perbauran kekristenan dengan salah satu kekayaan budaya yang penting sekali, yaitu adat yang dalam hal ini adat Batak Toba. Kelihatanya hidup berdampingan dengan damai antara keduanya dapat tercipta dengan adanya kearifan dari kedua belah pihak. Agama Kristen tidak berpendirian bahwa segala sesuatu yang merupakan kekayaan budaya pribumi itu kafir tetapi banyak darinya yang mengandung nilai-nlai yang tida bertentangan dengan nilai kristiani. Emikian pula sebaliknya masyarakat Batak tidak melihat agama Kristen itu sebagai kekuatan yang dapat menghilangkan budaya mereka. Mereka menilahtnya sebagai sesuatu yang memperkaya dan menyumbangkan nilai-nilai yang dapat membawa mereka kea rah kemajuan. Maka jadilah orang Batak itu adalah orang Kristen dan Kristen itu adalah agama orang Batak dan menjadi salah satu identitas mereka.

Tulisan yang ketiga "Terang itu Sudah Menyinari” khusus membicarakan kekristenan di kalangan Karo dengan pembicaraan lebih terpusat pada gereja yang 
besar yaitu Gereja Batak Karo Protestan (GBKP). Pengalaman yang sama dalam menghadapi misi yang mula-mula sama saja dengan pengalaman orang Toba yaitu adanya sikap konfrontatif tidak bersahabat dengan budaya dan peri kehidupan orang KAro. Orang Karo sendiri melihat agama Kristen dan para penginjil dengan penuh kecurigaan sebagai agen perkebunan Belanda. Namun pemahaman yang lebih baik dan lebih tepat di kemudian hari menimbulkan perdamaian antara kekristenan dan budaya pribumi. Sikap dan pemahaman tentang budaya pribumi pada awal penginjilan di kalangan orang Karo benar-benar menjadi salah satu faktor perintang, selain adanya prasangka yang menganggap para penginjil adalah kaki tangan pihak perkebunan untuk memperoleh lahan dan tenaga kerja. Kelihatannya kaitan anatara keduanya sangat kecil, meskipun kelihatannya kerjasama keduanya diikat pada awalnya melalui penyediaan dana. Namun perjalanan hidup misi selanjutanya harus mengandalkan upaya pendanaan sendiri.

Tulisan yang keempat, "Kekristenan dan Elite Sosial Baru” menguraikan timbulnya elite baru dalam kehidupan Karo khususnya dalam kehidupan Karo Kristen. Bab ini mengemukakan adanya dasar atau pedoman yang baru dalam menentukan posisi seseorang dalam hirarki struktur sosial yang lazim disebut dengan pelapisan sosial. Persayaratan menjadi pemuka atau elite dalam masyarakat menunjukkan terbukanya posisi-posisi elite tersebut kepada siapa saja yang mampu memenuhi persyaratan yang dituntut. Dengan demikian dapat atau tidaknya seseorang meraih posisi tersebut tergantung kepada kemampuan diri yaitu kenerja dan keberhasilan atau prestasi.

Tulisan yang terakhir "Dinamika Sosial dan Tantangan" mengemukakan tantangan yang perlu diantisipasi dan digumuli sehubungan dengan perubahan lingkungan sosial, budaya dan kehidupan orang-orang Kristen baik di pedesaan terlebih lagi di perkotaan.

\section{Dari Medan Area Ke Sipirok Area}

Buku yang diterbitkan April 1998 oleh Yayasan Merga Silima dituliskan atas gagasan Payung Bangun bersama Stoottroep Brigade -A- Tanah Karo (Barisan Harimau Liar) semasa perang Kemerdekaan tahun 1945-1950 untuk 
mengenang teman-teman yang telah gugur dan sebagai warisan sejarah bagi generasi penerus bangsa.

Buku ini dimaksud mengungkap perjuangan Stoottroep Brigade -A- Tanah Karo dan Karo Jahe sejak masih bernama Barisan Harimau Liar Resimen Tanah Karo dan Resimen Karo Jahe sebagai salah satu kekuatan perjuangan mempertahankan Negara Republik Indonesia hasil Proklamasi Kemerdekaan dari usaha penghancuran yang dilakukan oleh Belanda.

Penyusunan buku ini terutama mempergunakan naskah yang ditulis dalam bentuk ketikan oleh Payung Bangun yang merupakan pendiri Barisan Harimau Liar Tanah Karo setelah Proklamasi Kemerdekaan dan menjadi pimpinanaya dengan jabatan Komandan BHL Resimen Tanah Karo kemudian setelah reorganisasi dan integrasi ke dalam TNI sebagai Komandan TNI Brigade "A" Tanah Karo.

Uraian buku ini terdiri dari lima bab. Bab yang pertama menguraikan mengenai latar belakang diadakannya pelatihan ideologi dan kemiliteran terhadap pemuka masyarakat oleh Jepang. Payung Bangun melihat hubungannya dengan perhitungan Jepang, bahwa perang hanya dapat dimenangkan bila didukung oleh rakyat Indonesia. Rakyat perlu dipersiapkan bila perang gerilya harus dilakukan. Bab ini diakhiri dengan berita Jepang telah menyerah kepada sekutu dalam Perang Pasifik.

Bab kedua menguraikan tersiarnya proklamasi kemerdekaan Indonesia di Tanah Karo dan Sumatra Utara. Dalam bab ini diuraikan respon rakyat atas kemeredekaan yang telah dicapai. Selain itu diuraikan pula pembentukan sebuah pasukan perjuangan lascar rakyat yang diberi nama Barisan Harimau Liar (BHL). Dapat kita jumpai bagaimana upaya rakyat untuk tetap eksis mempertahankan tanah air di awal kemerdekaan.

Bab tiga menguraikan peristiwa agresi militer Belanda, dimana hubungan Belanda-Indonesia yang semakin memburuk karena adanya serangan dari Belanda dan mempengaruhi perkembangan perjuangan rakyat Indonesia, yang walaupun akhirnya Tanah Karo jatuh ke tangan Belanda dan ditandatanganinya perjanjian 
Renville, namun pasukan perjuangan tetap bertahan untuk merebut Tanah Karo melalui pertempuran Front Karo.

Bab empat menceritakan pengalaman BHL yang mengungsi ke daerah Tapanuli Selatan. Di saat yang bersamaan, ternyata Belanda juga melakukan serangan ke daerah Tapanuli Selatan sehingga BHL harus melakukan perlawanan di daerah Tapanuli Selatan dengan siasat perang gerilya. Di bab terakhir, menguraikan bagaimana akhir dari peristiwa dua agresi Belanda yang diselesaikan melalui Konferensi Meja Bundar (KMB) dan akhir dari Stoottoep Brigade A yang harus ikut bergabung dengan Tentara Nasional Indonesia.

\section{Kolonel Maludin Simbolon (Lika-Liku Perjuangannya dalam Pembangunan Bangsa).}

Buku ini diterbitkan oleh Pustaka Sinar Harapan pada tahun 1996 dengan jumlah halaman 397. Dalam buku ini Payung Bangun menceritakan lima babakan sejarah kehidupan Maludin Simbolon, yang pertama (1916-1935) mencakup masa kehidupan prasekolah dan sekolah yang memberikan pondasi awal bagi kepribadian dan kemampuan intelektualnya. Babakan itu berlangsung di Tapanuli (Tarutung, Pangururan, Pulo Tao, Simanindo dan Narumonda) dan di Jawa (Purbolinggo dan Solo).

Babakan yang kedua (1935-1961) berupa kehidupan sebagai guru dan ketentaraan Jepang. Babakan yang ketiga (1945-1956) dimana Maludin Simbolon ikut serta dalam perjuangan nasional Perang Kemerdekaan dan setelah perang usai mengambil alih medan di Sumatera Selatan dan Sumatera Utara.

Babakan yang keempat (1956-1961) merupakan masa perkembangan kehidupan nasional dan pergolakan daerah yang dialami oleh Maludin serta babakan yang terakhir (196101996) kehidupan sebagai warga Negara dan warga masyarakat. Pengungkapan kelima babakan sejarah kehidupan tersebut dimuat Payung Bangun ke dalam tujuh bab.

Peristiwa yang dialami oleh Maludin Simbolon menggambarkan bahwa orang Karo dalam hal ini Djamin Ginting berkhianat tetapi buku ini menggambarkan bahwa tidak benar Djamin Ginting berkhianat oleh sebab itu 
Maludin Simbolon memilih Payung Bangun untuk menuliskan buku ini, dikarenakan Payung Bangun adalah orang Karo yang berperan sebagai sejarawan.

\section{Melanchton Siregar (Pendidik dan Pejuang).}

Buku yang diluncurkan pada 7 Agustus 1987 mengenang ulang tahun Melachton Siregar ini, mengisahkan perjalanan hidup dan karir Melanchton Siregar hingga tutup usia 63 tahun pada pagi 24 Februari 1975. Melachton Siregar adalah tokoh langka yang sejak menjadi guru telah mengabdikan diri memajukan pendidikan. Selain itu Melachton juga mengabdikan diri sebagai politisi hingga akhir hanyatnya menjabat sebagai anggota Dewan Pertimbangan Agung (DPA) tanpa sedikitpun meninggalkan pengabdiannya pada bidang pendidikan.

Payung Bangun menuliskan kisah hidup Melachton sejak lahirnya, perjalanan hidupnya ketika meninggalkan daerah Sumatera Utara dan kehidupannya yang berkecimpung di partai politik dengan menjadi ketua umum terakhir dari Partai Kristen Indonesia (PARKINDO) sebelum berfusi ke Partai Demokrasi Indonesia (PDI) sebagai wakilnya pertainya beliau berperan sangat menonjol pada awal Orde Baru.

Payung Bangun menyelesaikan buku Melachton Siregar (Pendidik dan Pejuang) khususnya edisi kedua dibantu oleh Yayasan Komunikasi dan Yayasan Pendidikan Melanchton Siregar setelah melakukan berbagai wawancara tambahan, pencarian foto ilustrasi dan menyarankan sumbangan tulisan dari para kerabat Melancton. Edisi kedua akhirnya diterbitkan pada tanggal 7 Agustus 1998, disusun lebih baik sistematikanya dengan lebih merinci bab dalam sub bab yang berjumlah 24 sub bab yang keseluruhannya berjumlah 383 halaman.

\section{Titi Bambu (Saksi Bisu Tumpahnya Darah Pejuang)}

Titi Bambu merupakan karya dari Jamin Gintings dan disusun oleh Likas br. Tarigan kemudian disunting oleh Payung Bangun. Diterbitkan pada tahun 2009, "Titi Bambu” menceritakan perjuangan Resimen I di Front Karo Area sejak dilancarkannya Agresi Militer Belanda pada 21 Juli 1947 sampai dilaksanakannya Perjanjian Renville. 
Titi Bambu merupakan tulisan kenangan dalam masa perjuangan Jamin Gintings dan sekaligus melengkapi penulisan sejarah perjuangan bangsa Indonesia. Pengambilan judul "Titi Bambu" dilatarbelakangi oleh peristiwa yang sangat tragis yang dialami oleh sepasukan Kompi Markas Resimen I. Titi bambu yang dimaksud terdiri dari beberapa potong bambu yang dipakai untuk menyeberangi sungai yang sangat deras, Lau Biang. Tanpa mengetahui musuh sudah mengetahui penyebrangan itu dan bersiap untuk menyergap dari tempat ketinggian yang menyebabkan pasukan itu tidak dapat mengadakan perlawanan yang berarti. Korban yang tewas 12 orang dan 3 diantaranya tidak ditemukan karena hanyut di sungai sedangkan komandannya mengalami luka parah.

Perjuangan Jamin Gintings dan resimennya sepanjang perang kemerdekaan yang dikisahkan langsung oleh pelaku perang dan bukan ,merupakan biografi atau bibiografi. Perang kemerdekaan di Front Karo Area terbagi ke dalam tiga front pertempuran yaitu Front Pertempuran Karo Utara (daerah pertempuran Barisan Harimau Liar), Front Pertempuran Barat/Tengah (daerah pertempuran Napindo Resimen Halilintar) dan Front Karo Selatan (Daerah pertempuran Resimen I Divisi X Tentara Republik Indonesia).

Jamin Gintings digambarkan sebagai seorang pemimpin yang mampu memimpin meskipun dalam keadaaan yang paling sulit serta mendukung jiwa dan semangat kebersamaan dan persaudaraan tanpa harus mengabaikan hirarki ketentaraan dari semua pihak (Titi Bambu, 1975)

\section{Bukit Kadir (Detik-Detik Menegangkan Membela Merah Putih).}

Buku "Bukit Kadir" merupakan buku kembar dari buku "Titi Bambu". Buku ini buku kedua, meskipun terbitan pertamanya mendahului buku pertama “Titi Bambu" tahun 2009. Bukit Kadir mengungkapkan dan memaparkan peran dan perjuangan Resimen IV (tadinya Resimen I) dalam perang kemerdekaan setelah pelaksanaan Perjanjian Renville.

Buku ini berisi perjuangan dari tentara yang bermarkas di Macankumbang yang menjadi markas Resimen di pengungsian. Berbeda dengan perang yang dihadapi selama periode "Titi Bambu", periode "Bukit Kadir" mengenai serangan 
balik Resimen terhadap musuh yaitu Belanda. Prakarsa menyerang dalam perang kemerdekaan di "Bukit Kadir" lebih banyak dilakukan oleh Resimen yang dilancarkan secara frontal sebagaimana yang dilakukan Batalyon XIV yang dipimpin Kapten J. Minggu, dalam pengertian mempunyai garis pertahanan yang relatif tetap. Front utama disusun dan terbentang dari Laubaleng, Lau solo sampai Mardingding. Sedikit berbeda dengan itu, Batalyon XV yang beroperasi di Dataran Tinggi Karo, Langkat, Deli dan Serdang tidak menyususn garis pertempuran seperti itu. Taktik yang dijalankan benar-benar taktik menurut perang gerilya dengan prinsip pokok "serang dan menghindar" (hit and run).

Dalam buku tersebut kemudian dijelaskan lebih dalam mengenai taktik perperangan, yaitu kedua taktik yang dijalankan berpadu dalam suatu kerjasama dan saling bantu. Taktik yang dijalankan Batalyon XIV dapat memaku pasukan musuh pada suatu tempat sehingga terkadang sulit membantu pasukannya yang lain yang sedang memperoleh gempuran. Taktik Batalyon $\mathrm{XV}$ selain menimbulkan perasaan tidak aman dan tidak tentram di pihak musuh. Konsep perjuangan atau perang rakyat semsta benar-benar melahirkan perasaan memiliki dan perasaan ikut bertanggung jawab pada rakyat yang mendukung perjuangan. Pengibaratan rakyat dan tentaranya sebagai ikan dan air yang benar-benar menjadi kenyataan tidak sekedar ungkapan arif.

Buku ini menggambarkan keberhasilan perjuangan rakyat Indonesia dalam mempertahankan kemerdekaan dan tegaknya sebuah Negara merupakan perpaduan dari upaya perang, pengorbanan rakyat diplomasi dan dukungan internasional. Strategi dan taktik perang yang diterapkan mengingatkan kembali bahwa kelengkapan dan kemampuan persenjataan dan alat perlengkapan perang tidak seimbang antara yang kita miliki dan yang dipunyai Belanda. Semangat dan tekad adalah modal pokok dan utama dalam perjuangan.

\section{Puisi "Padamu Putera Sulung"}

Tidak hanya menulis mengenai sejarah, pendidikan dan kebudayaan, Payung Bangun juga pernah menorehkan sebuah puisi yang dimuatnya dalam buku Melanchton Siregar (Pejuang dan Pendidik) yang diperuntukkan sebagai 
hadiah dan pengantar dari beliau untuk Melanchton yang merupakan kakak ipar beliau. Puisi itu berbunyi sebagai berikut:

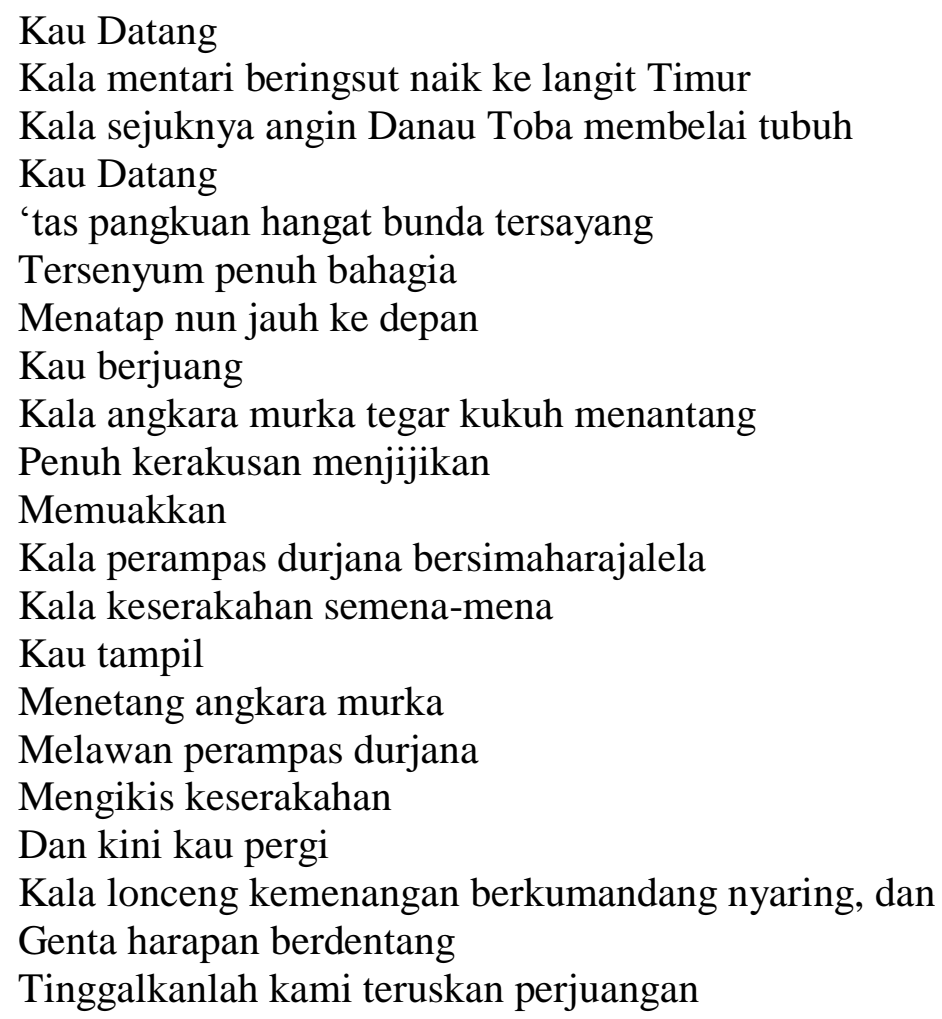

(Payung Bangun, 7 Agustus 1987)

\section{B. Konsistensi Pemikiran Payung Bangun}

Berkuliah di PTPG dan bertemu dengan dua guru besar M.Yamin dan Sadarjoen Siswomartojo membentuk Payung Bangun menjadi seorang yang berkualitas. Di sinilah cikal bakal pemikiran Payung Bangun mulai dibentuk khususnya ketika akhirnya beliau diminta M.Yamin untuk menjadi asisten mahasiswanya. Pemikiran kebangsaan M.Yamin merasuk ke dalam pemikiran Payung Bangun (Bangun: 2008: 118-120). Hal ini ditegaskan oleh Usman melalui wawancara, bahwa Payung Bangun sangat memperhatikan kesatuan bangsa Indonesia. Dimana menurut Payung Bangun, setiap suku bangsa harus diperlakukan sama, sederajat dan memperoleh keadialan yang sama yang merupakan hak-hak yang wajib diterima. Kesatuan Bangsa merupakan sesuatu yang harus diutamakan, mengingat banyaknya kaum minoritas yang dianggap tidak layak dan sederajat di Indonesia. Hal ini menunjukkan bahwa pemikiran 
yang dikemukakan Payung Bangun sedikit banyaknya dipengaruhi oleh M.Yamin sehingga kemudian melahirkan pemikiran beliau mengenai "Kesatuan Bangsa Indonesia" (Wawancara di Medan, Juni 2014).

Dari pemaparan karya-karya dan wawancara dengan informan, dapat dilihat bahwa Payung Bangun eksis dalam dunia pendidikan, sejarah dan kebudayaan. Tulisannya mengenai sejarah para tokoh telah dikenal oleh banyak kalangan khususnya para sejarawan dan membantu membuka cerita mengenai peristiwa pertempuran yang dialami oleh tokoh perjuangan bangsa. Tulisannya mengenai kebudayaan, lebih banyak condong kepada kebudayaan Karo dan atau Batak Toba dan beliau tetap mengkaji mengenai pendapatnya atas Kesatuan Bangsa Indonesia. Beliau kukuh berpendapat bahwa semua masyarakat Indonesia harus mendapat kedudukan yang setara dalam bidang apapun.

Namun pemikiran Payung Bangun dalam bidang pendidikan lebih mengarah kepada pentingnya pendidikan bagi generasi muda. Tidak ada kata putus asa dalam meraih ilmu pengetahuan. Setiap orang harus mencapai dan berusaha mengejar ilmu setinggi-tingginya. Selain itu dalam dunia pendidikan hal yang paling terlihat adalah kontribusi beliau dalam mengajar dan membimbing semua mahasiswanya hingga berhasil.. Baginya pendidikan tidak boleh “diproyekkan”. Itu sebabnya beliau tidak sungkan untuk berbicara dalam seminar, lokakarya, dan sebagainya tanpa bayaran dari pihak penyelenggara. Baginya pendidik harus mendidik dengan benar dan bertanggung jawab, itu sebabnya ia juga tidak akan menolak jika mahasiswanya mengajak beliau untuk berdiskusi mengenai topik perkuliahan dan atau yang lainnya. 


\section{PENUTUP}

Berdasarkan studi yang telah dilakukan maka penulis mengambil kesimpulan bahwa dedikasi Payung Bangun di dunia pendidikan dimulai ketika M.Yamin memintanya menjadi asisten mahasiswanya. Payung Bangun kemudian membantu M.Yamin mengampu beberapa mata kuliah selama satu tahun. Setelah satu tahun, beliau kemudian diangkat menjadi Asisten Tingkat II. Pengalaman menjadi asisten M.Yamin sangat bermanfaat dalam pengembangan kemampuan akademik Payung Bangun termasuk pengembangan kemampuan melayani mahasiswa dan penyampaian materi perkuliahan. M.Yamin sendiri diakui oleh Payung Bangun sebagai sosok yang berpengaruh besar terhadap kesusksesan karirnya dan membantu membentuknya menjadi seorang pengajar yang benar-benar mengabdi untuk pendidikan Indonesia. Pemikiran-pemikiran Payung Bangun sedikit banyaknya dipengaruhi oleh aktivitasnya bersama M.Yamin. Sebagai civitas akademik, menulis dan meneliti adalah suatu kewajiban yang harus dipenuhi. Kegiatan menulis yang pertama sekali dilakukan ketika ada keharusan untuk menulis skripsi yang berjudul "Pergerakan Kebangsaan Indonesia Abad XX" dan berlanjut terus hingga sampai akhir hayatnya beliau sedang menyiapkan sebuah buku yang rencana akan diterbitkan secepat mungkin. Banyak makalah yang telah dituliskan beliau salah satunya pada acara seminar Kebudayaan Karo dan Kehidupan Masa Kini, yang berjudul "Tuntutan Kehidupan Tahun 2000-an". Selain makalah, beliau telah menulis beberapa buku di antaranya "Pendidik dan Pejuang (Melanchton Siregar)", "Kolonel Maluddin Simbolon", "Dari Medan Area ke Sipirok Area", "Terang itu Sudah Menyinari - Perjumpaan Kekristenan dengan Suku Bangsa di Sumatera Utara”. 


\section{DAFTAR REFERENSI}

Abdullah, Taufik. 1985. Ilmu Sejarah dan Historiografi. Gramedia: Jakarta Abdulsyani, 1994. Sosiologi Skematika, Teori dan Terapan. Bumi Aksara: Jakarta Ahira, Ane. 2012.

Bangun, Payung. 1979. Bukit Kadir. Jakarta

1998. Dari Medan Area ke Sipirok Area. Yayasan Merga Silima: Jakarta

2008. Kisah Perjalanan Hidupku di Tengah-Tengah Keluarga, Perguruan Tinggi dan Masyarakat. Jakarta 1996. Kolonel Maludin Simbolon Lika-Liku Perjuangan dalam

Pembangunan Bangsa. Pustaka Sinar Harapan: Jakarta 1998. Melanchton Siregar Pendidik dan Pejuang. Yayasan Komunikasi: Jakarta 1981. Pelapisan Sosial di Kabanjahe(Disertasi) 2003. Terang itu Sudah Menyinari. UKI Press: Jakarta 1979. Titi Bambu. Jakarta

Gottschalk, Louis (terj. Nugroho Notosusanto). 1986. Mengerti Sejarah. UI Press: Jakarta

Hasbullah, Moeflih. 2012. Filsafat Sejarah. Pustaka Setia: Bandung

Hidayat, Bambang. 2004. Mozaik Pemikiran Sejarah dan Sains untuk Masa Depan. Kiblat: Bandung

Kochhar, S.K. 2008. Teaching is History. Grasindo: Jakarta

Koentjaraningrat. 2009. Pengantar Ilmu Antropologi. Rineka Cipta: Jakarta 2004. Kebudayaan Mentalitas dan Pembangunan. Gramedia: Jakarta

Kuntowijoyo. 2003. Metodologi Sejarah. PT.Tiara Wacana: Yogyakarta

Niel, Robert Van (terj. Ny. Zahara Deliar Noer). 1984. Munculnya Elite Modern Indonesia. Pustaka Jaya: Jakarta

Notosusanto, Nugroho. 1994. Sejarah Nasional Indonesia Jilid V. Balai Pustaka: Jakarta

Ricklefs, M.C. 2009. Sejarah Indonesia Modern 1200-2008. Serambi: Jakarta

Sejarah dan Kebudayaan, Depatemen. 1983. Pemikiran Biografi Kepahlawanan dan Kesejarahan Jilid I. Proyek Invebtarisasi dan Hokumentasi Sejarah Nasional: Jakarta

Sjamsuddin, Helius. 2007. Metodologi Sejarah. Ombak: Yogyakarta

Soewandi, Slamet. 2005. Pelangi Pendidikan Tinjauan dari Berbagai Persfektif. Universitas Sanata Dharma: Yogyakarta

Suryabrata, Sumadi. 2011. Metodologi Penelitian. PT.Rajagrafindo Persada: Jakarta

Tampubolon, D.P. 2008. Bunga Rampai Pemikiran Bahasa Lingusitik Pendidikan. Unimed Press: Medan

Tarigan, Sarjani. 1986. Bunga Rampai Seminar Kebudayaan Karo dan Kehidupan Masa Kini. Medan 